\title{
INTEGRATED PASSENGER TRANSPORT SYSTEM IN RURAL AREAS - A LITERATURE REVIEW
}

\begin{abstract}
The planning and organisation of public passenger transport in rural areas is a complex process. The transport demand in rural areas is often low, which makes it hard to establish and run a financially sustainable public transport system. A solution is integrated passenger transport that eliminates deficiencies and provides benefits for all participants in the public passenger transport process. This paper describes the impact of integrated passenger transport on mobility in rural areas and critically evaluates different literature sources. Integration of passenger transport in urban areas has been described in the context of rural areas, and the challenges of integration of public passenger transport specific to rural areas have been analysed. Through the application in urban and rural areas, the planning of integrated and non-integrated passenger transport has been functionally analysed. The analysis found an increase in the degree of mobility in the areas that use integrated passenger transport compared to the non-integrated one. This research of the literature review has identified the rural areas of mobility as under-researched. The mobility research can set up a more efficient passenger transport planning system in rural areas.
\end{abstract}

\section{KEY WORDS}

transport planning; rural area; public passenger transport; integrated passenger transport; mobility; flexible transport service;

\section{INTRODUCTION}

One of the prerequisites for rural areas to continue to exist is mobility. It encompasses various types of movement - cars, pedestrians, bicycles, and various public transport options. A high degree of mobility ensures faster population circulation from urban to rural areas and vice-versa, thereby enabling a more significant development potential of the urban areas. Rural areas are particularly appealing due to reduced pollution and stress, more privacy, and ultimately, higher life quality [1]. To achieve and improve the appeal of such areas, careful planning and operation of public transport options are essential. Good planning refers first and foremost to the sustainability of the public transport mode. The sustainability is seen in the number of passengers and revenue, adequate choice of vehicles (capacity, energy consumption, vehicle gauge, vehicle mass, wheelbase, number of door(s), type of door(s), etc.), and cost management combined with corresponding transport demand. Achieving sustainability requires a systematic organisation of public passenger transport.

The paper describes different aspects that commuters face in rural areas as well as the way in which these different aspects were perceived. Integrated passenger transport is the latest innovative transport planning and operating method originating from the scientific community. The paper also describes the advantages of such transport by using examples from practice. Passenger transport planning in several areas in the Republic of Croatia and Europe is also shown. The impact of different ways of passenger transport planning is presented from the perspective of passengers and transport operators. Finally, the paper draws conclusions in which it lists the drawbacks or loopholes in the previous research of passenger transport in rural areas.

\section{ROLE OF INTEGRATED PASSENGER TRANSPORT}

Public passenger transport is essential in realising a higher level of population mobility. The availability of public transport ensures that residents are not dependent on cars. Public transport should be at the service of marginalised population groups [2], 
which commonly reside in rural areas. Journeys should also be analysed from the viewpoint of the family. Owning a car is expected in average families who are not willing to risk not being able to make family and emergency journeys. In other words, not all journeys can make the switch from cars to public transport. The solution is to design public passenger transport in such a way that it takes over all journeys that do not belong to the group of family and emergency trips. For that to happen, public passenger transport must be integrated and a higher level of integration includes optimal resources [3].

Because of the specificity of public passenger transport in rural areas and the direction this paper aims to take, the authors of this paper have outlined the methodology of selecting relevant sources. This ensures focus on three key terms: (1) integrated passenger transport, (2) transport issues of public transport in rural areas, and (3) public transport service planning in rural areas. Figure 1 shows the road map of selecting the sources used in the subsequent analysis of integrated passenger transport in rural areas.

The onset of the issue in the current public transport organisation facilitates the need for integrated transport, which can be addressed in several different ways. Namely, it is a system of public transport that encompasses various modes of public transport into a unity [4]. It is also defined as a system for providing a door-to-door transport service [5]. Furthermore, integrated public transport is an organisational process which combines elements of transport planning and elements that create the transport service, regardless of the transport mode, service providers and institutions, all to increase economic and social benefits [6].

Integrated passenger transport system uses the advantages of transport modes engaged in the system and by combining modes, it greatly minimises the downsides of individual transport modes [7]. Such a system raises the issue of the branched structure of transport.

First and foremost, integrated passenger transport yields benefits such as reduced journey times due to higher departure frequency, reduced walking time, and time spent in a vehicle, reduced fares, and reduced need for smaller transport methods [8]. Furthermore, it offers numerous other benefits such as creating a single transport ticket, integrated timetables, reduced fares for some groups of passengers, while the number of passengers and thus the revenue increase [7].

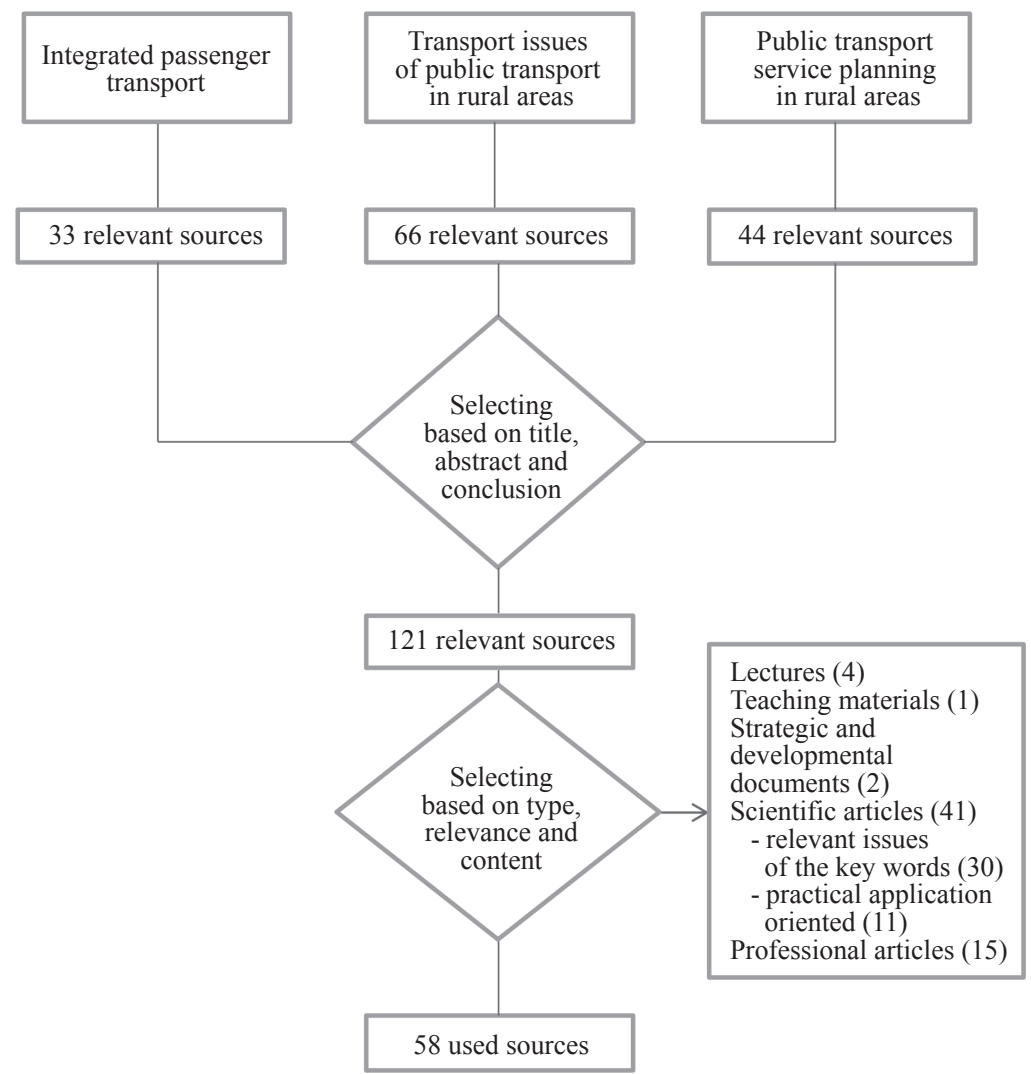

Figure 1-Road map of the detailed selection of sources 
Clearly, organising integrated passenger transport requires engaging a significant number of participants as well as elements of integration. The foundation of the system is the passenger, which means that public transport must take into consideration all kinds of passengers. Not all types of passengers can use the system under the same circumstances. For instance, persons of reduced mobility can only use the call service from when they exit the main route of integration to reach their place of residence [9]. Results from Italy [10] show that a route deviation strategy is more suitable to accommodate the rejected requests, that is, those for which it is impossible to schedule the call, than any Diala-Ride strategy. In Germany there exist dial-a-ride services that could serve as a possible guarantor for the preservation of personal mobility, especially in sparsely populated rural areas. Those systems offer public mobility-on-demand within given temporal and spatial restrictions [11]. To fill the gap between flexible transit services and conventional fixedroute systems there is a new category of transit policies, called demi-flexible operating policies. The key advantages of demi-flexible operating policies in providing affordable, efficient, and reliable transport service in low-demand operating environments is suitable for designing public transit in suburban and rural areas [12]. Research [13] concentrates on the vehicle routing operation of the demand-responsive connector system with on-demand stations. The results demonstrate that vehicle routing modelling and an optimised algorithm can confidently handle the daily operation of demand-responsive connector services with on-demand stations. There is an interesting solution for urban areas [14] with flexible feeder transit routing model that can serve irregular shaped networks. This approach with some constraint can be feasible in rural areas. The transport system must adjust to the needs of its users. Such planning becomes optimal when combining the pattern of passenger behaviour and artificial intelligence [15]. This would make it possible to use an artificially created passenger mobility routine.

Another method is to use the journey experience which is gained by interacting with passengers. According to [16], mobility planning must take into consideration the experience gained from using public transport. Such a relationship towards mobility ensures a better understanding of the needs of users, and greater use of public transport. Also, it would become a factor in making decisions on transport planning.

There are a few cases in which experience was not sufficient. It was used only in the analysis before planning procedures which is insufficient and should be used in all stages of transport planning [17]. Given that integration is a demanding task which depends on a range of elements that determine passenger behaviour, every change may cause non-sustainability of an element in the integration. Constant sustainability requires the engagement of science in drawing up methodology which would sustain an optimal system on all levels of transport technology. Decisions must not be political - they must rely on expert systems specialising in decision-making. Solutions are not easily noticeable. They are complex and demand software support from several perspectives [18].

\section{THE ISSUES OF PUBLIC TRANSPORT}

Before analysing the issue of public passenger transport in rural areas, first the rural areas need to be defined. These include several types of settlements (villages, municipalities and smaller towns). These areas are beyond the administrative grasp of cities - smaller settlements with fewer than 10,000 residents, all settlements with fewer than 5,000 residents and less than $25 \%$ of residents employed in the place of residence, i.e. in the secondary and tertiary economic activities, and settlements with fewer than 2,000 residents and less than $25 \%$ of residents employed in the place of residence in the tertiary and secondary economic activities. The share of the Croatian population living in rural areas is 45.8 per cent [19].

Public passenger transport stands for the provision of social service of transporting passengers from the point of origin to the point of destination by using different vehicles and operates based on the registered timetables. The service can be used by purchasing a ticket. Tariffing in integrated passenger transport systems with special emphasis in the research of tariff system is placed on resolving the issues of: (1) designing tariff zones, (2) maximising social welfare, (3) transport equity, and (4) transport disadvantages. Defining the tariffs can significantly affect the user behaviour and their preference for a transport method, so it is necessary to plan the tariff systems objectively to affect the transport demand 
positively [20]. According to the same author, the uniform tariff system in integrated passenger transport system is a set of principles based on which fares are offered for the transport services provided by all operators included in the system. The design of such a system is characterised by the principles of uniformity, zonality, and degressivity. When using tariffs, the fare is degressive, i.e. it becomes proportionately cheaper with distance, meaning that passengers travelling longer distances will pay less than the ones travelling over shorter distances or crossing fewer tariff zones, regardless of the price per kilometre. Therefore, it can be stated with some certainty that such a system is the backbone of a model for generating and distributing profit. It also determines the cost of fare for the provided service. Tariff system determines the zones of the encompassed area based on which the fares are calculated for the uniform transport service provided. The process of determining zones in the tariff system is referred to as zoning. Two issues arise from designing the zonal tariff system: (1) determining each zonal area - a division of zones, and (2) determining the optimal fare. Determining each zonal area is possible in several ways [20]: (1) relational, (2) unique, and (3) zonal. The relational tariff system is considered a fair tariff system because the price is paid for the service received per kilometre of travel. Unique tariff system that has the same transport service price for the whole service area is used in urban public transport but is not suitable for regional public transport because short journeys between two stops cannot have the same price as long-distance journeys covered in regional public transport. The third method commonly used in integrated passenger transport systems is the zonal tariff system, which is a combination of a relational and a single tariff system. The primary objective of defining the tariff system is to increase its appeal, which would then increase the number of users of the transport service, thereby increasing the income. Transport equity and care for peri-urban and rural areas would prevent their transport disadvantage and eliminate the need to utilise private vehicles for mobility.

Passengers in rural areas are regardless of age mostly dependent on personal vehicles. Even the elderly who do not own or drive a car are more prone to asking a family relative or a friend to give them a ride, rather than using public transport [21]. According to [22], this is justified because a single rural journey is not cost-saving enough compared to the ex- pense generated by public transport. The author also emphasises that a public transport journey in the rural area is significantly longer than when using a car.

The issue of rural areas also stems from the conflict between reduced availability to some settlements and traffic congestion and harmful gas emission [23]. According to [23], another problem is the fact that settlements in rural areas are quite dispersed. The low level of mobility is a transport issue which should be addressed by implementing transport measures and planning. Private entrepreneurs in rural areas must not be burdened with the theme of solving mobility issues - this must be dealt with by changing passenger behaviour or developing passenger responsibility [24]. Commuting to work by public transport should be an advantage of living in rural areas, not its downside. Unlike solving the problems in urban areas, resolving transport issues in rural areas requires innovation and a more versatile approach. The methodology used in the cities is inapplicable in rural areas [24]. Public transport in rural areas is mainly conceived in the standard methodology used for urban areas which ends in inadequate and undesired outcomes. Urban areas use planning methods founded on large sets of data, whereas rural areas data are largely scarce or unavailable. Data collection includes demographic and economic data according to the competent state body for statistics, transport network data (transport infrastructure, network lines, operating hours of lines, frequency), transport demand or passenger flows in various branches of transport. The survey collects more detailed data related to passenger flows, i.e. data related to travel data. The survey will cover questions like: where it travels from, where to travel, the purpose of travel, how long to travel, number of trips per week, when there would be adequately organised public transport whether to use it, whether passengers know what "Integrated passenger transport" is, the number of passengers in the vehicle, the city number on the license plate.

A rural area may have very few residents and if it aims to provide every passenger with high-quality service, it can do so only by ensuring cooperation between public transport operators and passengers. The lack of such cooperation and the cooperation between passengers and institutions that represent various transport modes leads to an expensive service which ultimately does not benefit the passenger. This, in turn, results in reduced public transport demand [25]. 
Rural area passengers are less likely to be stimulated by financial measures to use public transport. These measures must be accompanied by improvements in technical and technological solutions to provide passengers with a more practical and accessible public transport service [26]. Tourist journeys into rural areas are unsuitable for regular bus services as they reduce the quality of such journeys. Therefore, more significant innovation is required to make tourist journeys possible using public transport [27].

The following rural area transport service problems have been identified: (1) the level of demand is uncertain, (2) the number of service providers is low, (3) individual passengers have very specific journey demands, and (4) the service must include frequent departures for passengers dispersed over settlements far apart [28].

Collecting data can be divided into three basic categories: (1) transport supply data, (2) transport demand data, and (3) customer satisfaction. Transport supply data are information such as daily capacity, maximum hourly capacity, headway, frequency, number of departures, etc. Demand data are passenger volume, trip purpose, dwell time, origin/destination points, passenger boarding and alighting, etc. Customer satisfaction is traditionally collected with customer satisfaction survey [29].

Rapid advancement of information and communication technology has brought a revolution in the domain of Public Transport (PT) planning alongside other areas of transport planning and operations. Of particular significance are the passively generated big data sources (e.g. smart cards, detailed vehicle location data, mobile phone traces, social media) which have started replacing the traditional surveys conducted onboard, at the stops/stations and/or at the household level for gathering insights about the behaviour of the PT users. Types of big data in PT are: (1) smart card data, (2) mobile phone data, (3) GPS data, and (4) Automatic Vehicle Location (AVL). Only a quality mix of different data collection can gain feasible results for integrated public transport system [30].

Public transport planning is a complex process because of scarce data. Since the fundamental element of public transport are its users, it is clear that very few passengers use public transport. In fact, most residents opt for personal vehicles. There is also the issue of an outdated public transport route organisation and a slow response to the needs of passengers.
Clearly, the existing level of mobility was not used to allocate needed resources which results in negative impact.

\section{PLANNING PUBLIC PASSENGER TRANSPORT SERVICES}

Planning public transport in rural areas is complex and a great number of participants and elements are engaged in the process. The objective is to increase the level of mobility.

Mobility is often seen as a mere rational activity even though it should not be. In such a case, there is only the given-gained relationship [16]. Since mobility is the result of planning on all levels of hierarchy, clearly all levels affect mobility. There are short-term, long-term and operational plans being carried out using development strategies, guidelines and the operational transport organisation. Planning has been analysed in various examples in Croatia, the Czech Republic, Switzerland and the United Kingdom.

Administratively, Croatia is divided into twenty counties and the City of Zagreb. The way of organizing public transport of passengers in three counties is described. First Šibenik-Knin County where the City of Sibenik is the centre of the county and Knin, a small town in the rural area of the county. Sisak-Moslavina County is based in the City of Sisak, and Moslavina is a mountain in the same county. Zadar County bears such a name because its headquarters is in the City of Zadar.

Public transport in Šibenik-Knin County includes (1) the bus service, (2) ferries, and (3) the railway. In mainland transport, there are positive results due to the competition between bus and railway companies for the same destinations in long-distance travel. Apart from the competition, cooperation and proactive transport managed can also help to advance the service and lower the fares. Railway has the highest cost but also the highest journey time. These drawbacks are the result of poor public transport planning. There is also no single fare for transferring between transport modes. Timetables are not integrated and there are no integration terminals despite the favourable location. These issues can be resolved by introducing integrated passenger transport [31].

Ferry transport is also in poor condition seen from the standpoint of the optimal use of resources. According to the analysis [32], the number of vehicles exceeds demand manifold. Apart from being 
the result of poor planning of state routes, the transport organisation of smaller private vessels is also to blame. Resolving these issues does not include reducing the number of vessel departures because this would lead to people moving away from the islands [32].

A positive example is found only in the summer in the Šibenik area. The Mandalina borough is connected to the city centre by a ferry route. The full potential of this route remains unused, however, due to the branched transport. Nevertheless, it does reduce journey time [33].

Sisak-Moslavina County is one of the counties facing mass emigration and one of the reasons lies in the poorly developed transport system. Despite the favourable position, public transport has poor planning, poor accessibility, routes have been poorly devised and the integration level is sub-par. Residents in rural areas depend largely on cars, mostly due to the low public transport frequency. Better route planning with destinations in the county's capital would lead to a more satisfactory demand for public transport [34].

In the Zadar County, the transport policy is not being carried out in accordance with professional guidelines. A large number of residents have moved from rural into urban areas mainly because of the extremely poor public transport. The current level of mobility has not been analysed nor used for further planning. Railway transport, although routed in a very favourable manner, has not been used. Public transport road routes run parallel with the railway routes. The only trace of integration is found in urban and suburban road transport, while railway and ferries remain isolated [35].

Public transport organisation in rural Switzerland has static and dynamic areas in the area of Graubünden's Lower Engadine and Val Müstair. The backbone of the transport is the railway, while buses transport passengers to the railway. Case in point: the railway transport terminates at Scuol. The trains arrive from the west - one from Chur via Davos and depart from Saint Moritz for Scuol. An eastbound bus route departing for Scuol has feeder routes that branch out of the main route for return journeys. In other words, feeder routes complement the main route for departure journeys. There are smaller settlements beyond the reach of feeder routes, but there are other, more flexible transport services available, which are usually more costly and complex to plan. Operational times are 12 to
14 hours for buses, with railway staying in operation longer. It is also stated that in certain periods, taxi-buses can collect passengers if they ask to be collected by registering in advance. The passengers then board the buses 30 minutes earlier [36].

Another example of integrated passenger transport is in the Czech Republic. The Czech Republic is divided into thirteen provinces. One of the provinces is the South Moravian Region, named by the southern part of the historically important region of Moravia. Integrated passenger transport in the South Moravian Region proves that the existence of such transport planning is first and foremost the result of political interests. Economically, such as system is not efficient and it depends largely on transport policies. A paradigm shift in integrated transport planning is needed for a higher level of sustainability to be ensured. There is too much unused capacity and also a few adjustments to the transport demand [37].

The United Kingdom pays particular attention to combining static and dynamic transport services. Great emphasis is placed on marginal population groups and transport is specially regulated for the situations such as hospital transport in rural areas. In the countries of the UK, there is legislation requiring that transport services be offered for passengers who are physically disabled and require urgent medical care. Since these are rural areas, a logical step is to offer flexible integrated transport. To provide more favourable services, a form of corporate social responsibility for public transport was introduced $-\mathrm{a}$ driver volunteer [38]. This means that flexible integrated transport relies on cooperating with the local community for health reasons. Such an organisation of public transport in rural areas may become good practice, especially for the transport to state institutions of general benefit.

All these planning cases have one thing in common - mobility is being ignored. Mobility remains unchanged after initial planning. The planning process must be bidirectional due to the exceptionally complex process of collecting and processing operation data.

For public transport to maintain a high level of sustainability and mobility on the operational level after the integration process, a single integrated transport organisation must be set up. Only then can sustainability be analysed continuously and improved [39]. This conclusion leads to the need for bidirectional transport planning which includes the current state of mobility as the starting point. The 
current situation demands changes in the use of the capacity of transport modes. Changes in vehicles in public transport can lead to a change in transport demand. Routes and vehicles operating on it can be more attractive, journey times can be reduced, and the quality can be improved while reducing cost.

Operational planning of integrated transport is not always without fault. Integration is frequently being harmonised using integrated timetables. However, this is insufficient due to the incidents that occur in the operation of integrated passenger transport. These incidents may arise from traffic congestions. In one research [40], the issue was detected and a tactic-based control was developed. Incidents lead to increases in journey times and delays of one transport mode which then causes delays in another. The tactic-based control accomplishes a reduction in journey times of vehicles involved in incidents. In other words, integration is achieved despite one transport mode being delayed. Thereby, the level of reliability of the use of integrated transport remains high.

Public transport is often perceived as more time-consuming than travelling by car, which is a fallacy [41]. What makes journey times seem longer in terms of the overall passenger demand is the walking time to the first transport mode and the walking time from the final station to the destination. Walking times should be included in planning. In the context of rural areas, the term passenger denotes an individual, which does not create an obstacle in the transport service on demand. In mass transport, especially in rush hours, the number of passengers exceeds transport capacity which leads to greater passenger density in vehicles. However, this hardly ever happens in rural areas [42].

Planning integrated transport service by using bi-objective integrating software models takes into consideration the demands of passengers and operators. Passengers demand higher frequency and operators require optimal use of resources [43]. What is the downside in this method is the fact that the stochastic character of the transport processes is being ignored - only direct costs are taken into consideration when optimising the resources. A decrease in the functionality obtained with this method is justified by the given-gained ratio using the Pareto efficiency.

Some studies indicate that only by adhering to the key principles of integrated timetables can there be a minimisation of all costs in transport planning.
The essential principles are related to the integration point in which integrated timetables find meaning because passengers can achieve whatever transport they need quickly in any direction because of the integration point. This type of transport planning relies on precision and reliability of each route. Even the slightest issue on the route may lead to significant changes in passenger transport on a wider scope [44]. To understand the concept of a clockface timetable, a parallel was made with air transport. All planes land at an airport at the same time and depart at the same time as well. Therefore, all passengers can transfer without greater delays and continue their respective journeys regardless of the distance to destination [45]. Railway offers clockface transport services in 15,30 , or 60 -minute intervals [46]. Such networks have integration points in which transport services converge as complements to the main route [47]. In a properly planned integrated public transport network, it is not only the individual route that matters but also the entire transport system [48].

For integration points to be planned accordingly, it is essential to analyse the transport modes that best correspond to the scope of the transport service. The primary analysis tool recommended for modal allocation is the Logit model because it offers the most reliable output variables for more than two modes of transport. By applying the model, we can obtain numerical values for assessing sections of integrated passenger transport [49].

Study [50] explores the commuters' perception of transfers by adopting Weber's Law "Just Noticeable Difference". The commuter's perception of travel time and travel cost is analysed and the travellers with a longer travel time are more willing to make transfers. All taken together, the study illustrates that despite the existing negative perception PT users have about transfers, they are willing to use the routes with transfers given the travel time and travel cost savings.

Travel information is one of the factors that contribute to the quality of public transport and especially the integrated public transport system. There is need for establishing integrated multimodal travel information (IMTI). IMTI has the following modules: (1) travel information, (2) journey - three different stages (pre, during and post), (3) public transport customers, (4) public transport service quality, and (5) determinants of expected service quality. This mix approach is useful in all three-phase 
evaluation of the integrated public transport system: (1) planning, (2) operating, and (3) analysis [51]. The time spent on transport includes the movement of vehicles (passenger transport) from the departure terminal through the first and all subsequent stops for changing passengers to the final terminal. Since the timetable determines the time of arrival for all stops and the final terminal, for the purpose of time analysis it is necessary to record the times of arrival and departure from the stop, as well as the number of passengers alighting and the number of passengers boarding. The time of stay at the stop depends on passengers alighting and boarding and the issuance/acceptance of their luggage. The movement of the bus (passenger transport) ends with the transport of passengers to the final terminal. At the final terminal, the bus will stay as long as it takes to get all passengers out and check out their luggage (on average, a driver needs two to three minutes to open/ close luggage compartments, and can issue two to four pieces of luggage to passengers in one minute). After the departure of the passenger, the final zero bus moves to the nearest parking lot and stops until the start of the return ride. When performing a return trip, all processes are the same [52].

The integration of conventional bus lines and flexible bus routes can yield numerous benefits. For the transport service to be feasible, a modal allocation of transport needs to be carried out. In the case of [53], the integration included two bus routes by using a hybrid high transport demand, and for the flexible routes, the optimisation method was used. The result is exceptionally favourable for conventional buses in cases of low demand. It should be noted that the research was carried out with artificially established limitations. Such limitations include the transport demand being allocated according to the scope area, unlimited factors of boarding buses (e.g. capacity), and all buses adhering to the timetable (the incident factor eliminated). Clearly, in real-world situations, traffic does not follow the limitations and the aforementioned area has not been researched enough to take into consideration such factors. Correcting such deviations can be achieved by planning passenger transport from the standpoint of the current level of mobility.

The rural area does not only include the areas with low population density in the mainland but also the urban peripheral archipelago. Since there is a close correlation between population density and public transport availability, it is clear that the means of including islands that comprise the peripheral archipelago must exclusively rely on better transport service planning. The difference between rural and urban lies in transport modes, first and foremost. To travel to the islands, people must use ferries [54]. The transport service quality is what keeps islands populated and more appealing than before [55]. Island transport planning is also what the Logit model can do [55]. The same methodology applied to the mainland areas was used to determine the current state of mobility. The issue is how to plan on. The usual method is to make minor alterations in the transport organisation, yet such modifications do not comprise complete passenger transport planning.

Flexible transport service is mainly carried out to eliminate costs of the existing passenger transport service which was poorly planned. To implement flexible transport service in rural areas, the following recommendations were issued [56]: The service must be user-centred, focus on the needs of users and the cooperation between operators of the flexible transport service, understanding, and constant monitoring of the market. The service must be designed to suit the specific demands of users. Clearly, there is no single unified method of implementing the flexible transport service. Research methodology can be based on these recommendations but under the condition that each of the recommendations is researched within the context of the area in which passenger transport is carried out.

By adequately implementing integrated passenger transport on the regional level, it is possible to achieve 81 per cent user satisfaction [57]. The existing methodology for planning mobility is inadequate to provide a sufficiently good result in the long run [58].

\section{CONCLUSION}

This research and review of the literature on integrated passenger transport planning in rural areas provided an understanding of all the individual segments that make up this topic as well as what connects them. The research on passenger transport planning, integrated passenger transport as well as passenger transport in rural areas have been critically analysed and synthetically presented. What connects these segments and what is the end product of their connection is mobility. Transport planning always results in a certain level of mobility. When planning passenger transport in rural areas, there are 
certain shortcomings in terms of capacity utilisation, poor user service, and inadequate public transport coverage of an area. When such a situation arises, planning becomes the exception in which only minor modifications to public transport are made. One of the reasons for this is the lack of interest by the scientific community to carry out research in areas with very few data, when in fact this should be a challenge the scientific research should rise to.

Every passenger transport planning is one-directional which leaves current mobility disregarded. Passengers are placed at the centre of numerous scientific papers but the planning paradigm remains unchanged. Planning should be done in the same way but should include a greater number of user-satisfaction elements. Inadequate planning is incomplete, which has been shown by the previous research. Since urban areas are different from rural areas based on factors such as population, infrastructure, investment returns and appeal, it is clear that the same planning paradigm is inapplicable. From the standpoint of the current level of mobility, planning public transport has not been researched enough, which is what the new paradigm should aim to achieve. The need for such a paradigm is clear. If there is an economic loss for passengers, the capacities will remain unused, and if operators experience losses, the service will eventually lack quality. Future research of passenger transport planning in rural areas from the standpoint of mobility should aim to collect and process data based on which optimal passenger transport planning should be achieved both for passengers and the operators. This would ultimately lead to increased transport demand. The purpose of passenger transport is to enable satisfactory mobility in meeting certain needs. In order to facilitate the planning of the organisation of passenger transport, it is necessary to assess the degree of mobility in a particular area. The assessment of the degree of mobility will enable the determination of the mobility of residents in the existing public passenger transport system and after the introduction of integrated passenger transport. The degree of mobility determines how successfully the organisation of passenger transport in a rural area has been implemented. Based on the established degree of mobility, more efficient planning of public passenger transport in rural areas can be influenced. The existence of the possibility of assessing the degree of mobility is necessary because the traffic, demographic and economic criteria for determining mobility are variable in numerically low values and determining them in relation to the assessment requires substantial financial resources and is organizationally demanding.

BRANIMIR MARETIĆ, doktorand ${ }^{1}$

E-mail: branimir.maretic@gmail.com

Dr. BORNA ABRAMOVIĆ ${ }^{1}$

E-mail: borna.abramovic@fpz.hr

${ }^{1}$ Sveučilište u Zagrebu, Fakultet prometnih znanosti

Vukelićeva 4, 10000 Zagreb, Hrvatska

\section{INTEGRIRANI PRIJEVOZ PUTNIKA U RURALNIM PODRUČJIMA-PREGLED LITERATURE}

\section{SAŽETAK}

Planiranje i organizacija javnog prijevoza putnika $u$ ruralnim područjima složen je proces. Prijevozna potražnja u ruralnim područjima često je niska, što otežava uspostavljanje i pokretanje financijski održivog sustava javnog prijevoza. Kao rješenje nameće se integrirani prijevoz putnika koji neutralizira nedostatke i pruža koristi svim sudionicima u procesu javnog prijevoza putnika. Ovaj rad opisuje utjecaj integriranog prijevoza putnika na mobilnost $u$ ruralnim područjima $i$ kritički ocjenjuje različite literaturne izvore. Integrirani prijevoz putnika u urbanim područjima opisan je te postavljen u kontekst ruralnih područja, a analizirani su i izazovi integriranog prijevoza putnika specifični za ruralna područja. Na različitim primjerima u urbanim i ruralnim područjima funkcionalno je analizirano planiranje integriranog $i$ neintegriranog putničkog prijevoza. Analizom literature utvrđen je porast mobilnosti u područjima koja koriste integrirani prijevoz putnika u odnosu na neintegrirani. Ovim pregledom literature mobilnost ruralnih područja prepoznata je kao nedovoljno istraženo područje. Istraživanje mobilnosti može dovesti do uspostave učinkovitijeg sustava planiranja prijevoza putnika u ruralnim područjima.

\section{KLJUČNE RIJEC̆I}

prometno planiranje; ruralna područja; javni prijevoz putnika; integrirani prijevoz putnika; mobilnost;

fleksibilna prijevozna usluga;

\section{REFERENCES}

[1] Lukić A. About theoretical approaches to rural areas. Croatian Geographical Bulletin. 2010;72(2): 49-75.

[2] Gašparović S. Theoretical postulates of transport disadvantage. Croatian Geographical Bulletin. 2016;78(1): 73-95.

[3] Kopecká P, Švetak J. The integrated public transport system. Pomorstvo - Scientific Journal of Maritime Research. 2013;1: 149-56.

[4] Stopka O, Bartuška L, Kampf R. Passengers' evaluation of the integrated transport systems. Naše more. 2015;62(3): 153-157. 
[5] Janic M. Integrated transport systems in the European Union: An overview of some recent developments. Transport Reviews. 2001;21(4): 469-497.

[6] Poliaková B. Key success factors of integrated transport systems. Proceedings of the $13^{\text {th }}$ International Conference "Reliability and Statistics in Transportation and Communication" (RelStat '13). 2013;(16-19): 83-90.

[7] Government of the Republic of Croatia. Transport Development Strategy of the Republic of Croatia for the period from 2014 to 2030; 2014.

[8] Preston J. What's so funny about peace, love and transport integration? Research in Transportation Economics. 2010;29(1): 329-338.

[9] Posada M, Andersson H, Hall CH. The integrated dial-aride problem with timetabled fixed route service. Public Transport. 2017;9(1-2): 217-241.

[10] Pratelli A, Lupi M, Farina A, Pratelli C. Comparing Route Deviation Bus Operation with Respect to Diala-Ride Service for a Low-Demand Residential Area. Proceedings of the Seventh International Conference on Data Analytics, DATA ANALYTICS 2018, 18-22 Nov. 2018, Athens, Greece; 2018. p. 141-148.

[11] König A, Grippenkoven J. From public mobility on demand to autonomous public mobility on demand Learning from dial-a-ride services in Germany. In: Sucky E, Kolke R, Biethahn N, et al. (eds.) Mobility in a Globalised World 2016. Bamberg, Germany: University of Bamberg Press; 2017. p. 295-305.

[12] Qiu F, Shen J, Zhang X, An C. Demi-flexible operating policies to promote the performance of public transit in low-demand areas. Transportation Research Part A: Policy and Practice. 2015;80: 215-30.

[13] Shen J, Yang S, Gao X, Qiu F. Vehicle routing and scheduling of demand-responsive connector with on-demand stations. Advances in Mechanical Engineering. 2017;9(6): 1687814017706433

[14] Lu X, Yu J, Yang X, Pan S, Zou N. Flexible feeder transit route design to enhance service accessibility in urban area. Journal of Advanced Transportation. 2016;50(4): 507-21.

[15] Liang Q, Weng J, Zhou W, Santamaria SB, Ma J, Rong J. Individual Travel Behavior Modeling of Public Transport Passenger Based on Graph Construction. Journal of Advanced Transportation. 2018; Article ID: 3859830.

[16] Schiefelbusch M. Rational planning for emotional mobility? The case of public transport development. Planning Theory. 2010;9(3): 200-222.

[17] Schiefelbusch M. Analysing and Assessing the Experience of Traveling by Public Transport. Journal of Public Transportation. 2015;18(4): 46-72.

[18] Matzoros A. Decision Support Systems for Public Transport Management: The Athens Public Transport Authority Project. Transportation Planning and Technology. 2002;25(3): 215-237.

[19] Lukić A. Rural area - Approach to definition. Croatia and European Union Funds 2014-2020: Investing in the Future. Zagreb: Faculty of Sciences, Department of Geography; 2013.

[20] Šipuš D, Abramović B. Tariffing in Integrated Passenger Transport Systems: A Literature Review. Promet - Traffic\&Transportation. 2018;30(6): 745-51.

[21] Hanson TR, Hildebrand ED. Can rural older drivers meet their needs without a car? Stated adaptation responses from a GPS travel diary survey. Transportation. 2011;38(6): 975-992.

[22] Pucher J, Renne JL. Rural mobility and mode choice: Evidence from the 2001 National Household Travel Survey. Transportation. 2005;32(2): 165-186.

[23] Stokes G. Rural transport policies in the 1990S. Proceedings of the Institution of Civil Engineers - Transport. 1995;111(3): 245-253.

[24] Soder M, Peer S. The potential role of employers in promoting sustainable mobility in rural areas: Evidence from Eastern Austria. International Journal of Sustainable Transportation. 2017;12(7): 541-551.

[25] Reis V, Macario R. Promoting integrated passenger transport solutions using a business approach. Case Studies on Transport Policy. 2015;3(1): 66-77.

[26] Dargay JM. Determinants of car ownership in rural and urban areas: a pseudo-panel analysis. Transportation Research Part E: Logistics and Transportation Review. 2002;38(5): 351-366.

[27] Dickinson JE, Robbins D. Representations of tourism transport problems in a rural destination. Tourism Management. 2008;29(6): 1110-1121.

[28] Velaga NR, Rotstein ND, Oren N, Nelson JD, Norman TJ, Wright S. Development of an integrated flexible transport systems platform for rural areas using argumentation theory. Research in Transportation Business \& Management. 2012;(3): 62-70.

[29] Pticina I. The methodology of data collection about public transport service quality. Proceedings of the $11^{\text {th }} \mathrm{In}$ ternational Conference "RELIABILITY and STATISTICS in TRANSPORTATION and COMMUNICATION; 2011.

[30] Zannat KE, Choudhury CF. Emerging big data sources for public transport planning: A systematic review on current state of art and future research directions. Journal of the Indian Institute of Science. 2019;99(4): 601-619.

[31] Maretić B, Abramović B. Using public transport in rural area: Case study Šibenik-Knin County. Proceedings of the International Scientific Conference "Science and Traffic Development” (ZIRP 2019); 2019. p. 231-240.

[32] Janković AM, Ljubić-Hinić M, Beović B. Martime Liner Transport of Passengers from the District of Šibenik. Challenges of Today, Proceedings of the Polytechnic of Šibenik; 2013. p. 455-463.

[33] Pražen A, Olivari L, Maretić B. Innovative tourism as a driver of traffic transformation of the City of Šibenik. International Scientific and Professional Conference, Challenges of Today: Sustainable Coastal and Maritime Tourism. Polytechnic of Šibenik; 2017.

[34] Šipuš D, Abramović B. The possibility of using public transport in rural area. Procedia Engineering. 2017;(192): 788-793.

[35] Abramović B, Šipuš D, Troskot J. Organization of Railway Traffic in Integrated Public Passengers Transport System: The case of Zadar County. CMDTUR; 2018.

[36] Petersen T. Watching the Swiss: A network approach to rural and exurban public transport. Transport Policy. 2016;(52): 175-185.

[37] Št'astná M, Vaishar A, Stonawská K. Integrated Transport System of the South-Moravian Region and its impact on rural development. Transportation Research Part 
D: Transport and Environment. 2015;(36): 53-64.

[38] Mounce R, Wright S, Emel CD, Zeng C, Nelson JD. A tool to aid redesign of flexible transport services to increase efficiency in rural transport service provision. Journal of Intelligent Transportation Systems. 2017;22(2): 175-185.

[39] Mrnikova M, Poliak M, Simurkova P, Reuter N. Why is important establishment of the organiser in integrated transport system in Slovak republic? XI International Science-Technical Conference Automotive Safety; 2018.

[40] Nesheli MM, Ceder A. Use of Real-Time Operational Tactics to Synchronise Transfers in Headway-Based Public Transport Service. Transportation Research Record: Journal of the Transportation Research Board. 2016;(253): 103-112.

[41] Jenelius E. Public transport experienced service reliability: Integrating travel time and travel conditions. Transportation Research Part A: Policy and Practice. 2018;(117): 275-291.

[42] Leurent F. Transport capacity constraints on the mass transit system: A systemic analysis. European Transport Research Review. 2011;3(1): 11-21.

[43] Sun Y, Maoxiang L. Bi-objective optimisation for multimodal transportation routing planning problem based on Pareto optimality. Journal of Industrial Engineering and Management. 2015;8(4): 1195-1217.

[44] Walter S. Integrated periodic timetable scheduling - Towards an integrated timetable across central Europe. $2^{\text {nd }}$ International Conference on Road and Rail Infrastructure (CETRA); 2012. p. 855-861.

[45] Vuchic V, Clarke R, Molinero A. Timed Transfer System Planning, Design and Operation. US Department of Transportation Washington D.C.; 1981.

[46] Vuchic V. Urban Transit: Operations, Planning and Economics. John Wiley \& Sons. New Jersey; 2017.

[47] Pharoah T, Apel D. Transport concepts in European cities. Ashgate Publishing Company; 1997.

[48] Clever R. PART 3: Intermodal: Integrated Timed Trans- fer: A European Perspective. Transportation Research Record: Journal of the Transportation Research Board. 1997;(1571): 107-115.

[49] Chmelík J. Assessments of Modal Split in Long-distance Passenger Transport. Review of Economic Perspectives. 2015;15(1): 49-69.

[50] Chowdhury S, Ceder AA, Schwalger B. The effects of travel time and cost savings on commuters' decision to travel on public transport routes involving transfers. Journal of Transport Geography. 2015;43: 151-9.

[51] Grotenhuis JW, Wiegmans BW, Rietveld P. The desired quality of integrated multimodal travel information in public transport: Customer needs for time and effort savings. Transport Policy. 2007;14(1): 27-38.

[52] Al-Mudhaffar A, Nissan A, Bang KL. Bus stop and bus terminal capacity. Transportation Research Procedia. 2016;14: 1762-71.

[53] Chen L, Schonfeld P, Miller-Hook E. Welfare maximisation for bus transit systems with timed transfers and financial constraints. Journal of Advanced Transportation. 2015;50(4): 421-433.

[54] Makkonen T, Salonen M, Kajander S. Island accessibility challenges: Rural transport in the Finnish archipelago. European Journal of Transport and Infrastructure Research. 2013;(13): 274-290.

[55] Laird JJ. Valuing the quality of strategic ferry services to remote communities. Research in Transportation Business \& Management. 2012;(4): 97-103.

[56] Liu T, Ceder A, Chowdhury S. Integrated public transport timetable synchronisation with vehicle scheduling. Transportmetrica A: Transport Science. 2017;13(10): 932-954.

[57] Valaskova M, Krizanova A. The passenger satisfaction survey in the regional integrated public transport system. Promet - Traffic\&Transportation. 2008;20(6): 401-404.

[58] Gogola M, Hocova M. Deurbanisation and Mobility. Transportation Research Procedia. 2016;(14): 1193-1200. 